\title{
Iatrogenic hypocalcaemia following magnesium sulphate therapy in a patient with tetanus
}

\author{
ES Wijewickrama', UCL Hewage ${ }^{2}$ and SD Jayaratne ${ }^{3}$
}

(Index words: Absence of clinical signs of hypocalcaemia, management, parathormone level)

Magnesium sulphate is increasingly being used in clinical practice, especially in the management of eclampsia, tetanus and severe bronchial asthma. Magnesium is known to influence the body's calcium homeostasis. Hypomagnesaemia leads to hypocalcaemia by inducing resistance to parathormone $(\mathrm{PTH})$ in bone and kidneys and by decreasing PTH release. Interestingly, hypermagnesaemia also can cause hypocalcaemia by suppressing release of PTH and by inhibiting renal tubular calcium reabsorption [1]. Though hypomagnesaemia is mentioned commonly as a cause of hypocalcaemia in medical textbooks, the influence of hypermagnesaemia on serum calcium levels is often forgotten. We report here a case of hypocalcaemia caused by high serum magnesium levels.

A 70-year old man was admitted to the Professorial Medical Unit at the Teaching Hospital, Colombo South with a history of inability to open the mouth for 3 days. On the second day after admission he developed repeated muscle spasms and a clinical diagnosis of tetanus was made. The patient was transferred to the intensive care unit and started on a magnesium sulphate infusion at the rate of $2 \mathrm{~g} / \mathrm{h}$.

He was ventilated initially via an endotracheal tube and later via a tracheostomy tube. A 20000 units of human tetanus immunoglobulin were administered. He also had a superadded lower respiratory tract infection and was treated initially with intravenous crystalline penicillin, cefuroxime, metronidazole and later with ceftazidime.

Serum calcium was measured as a routine investigation. It was found to be low. As expected serum magnesium levels were high. Intact serum PTH level was within the normal range (Table 1). Clinical signs of hypocalcaemia were absent in this patient despite the presence of significantly low serum calcium.

Hypocalcaemia was initially treated with intravenous calcium gluconate and the patient was started on a regular dose of calcium lactate. High serum magnesium levels were thought to be the cause for the low serum calcium and the magnesium sulphate infusion was tailed off. Serum calcium returned to normal once the serum magnesium levels were corrected. Serum PTH level also started rising. The patient made an uneventful recovery. Serum calcium levels remained normal while the patient was in the ward and after discharge.
Table 1. Change in serum calcium levels with change in serum magnesium levels

\begin{tabular}{lccc}
\hline & $\begin{array}{c}\text { While on } \\
\mathrm{MgSO}_{4} \\
\text { infusion } \\
2 \mathrm{~g} / \mathrm{hr}\end{array}$ & $\begin{array}{c}\text { When } \\
\mathrm{MgSO}_{4}\end{array}$ & $\begin{array}{c}\text { Normal } \\
\text { infusion } \\
\text { wastailed } \\
\text { off }\end{array}$ \\
& \multicolumn{3}{c}{} \\
& 1.7 & 2.38 & $2.25-2.6$ \\
\hline $\begin{array}{l}\text { Serum total calcium }(\mathrm{mmol} / \mathrm{L}) \\
\text { Serum ionized calcium }\end{array}$ & 0.94 & 1.24 & $1.12-1.32$ \\
$\quad(\mathrm{mmol} / \mathrm{L})$ & 3.6 & 1.54 & $1.3-2.1$ \\
$\begin{array}{l}\text { Serum magnesium }(\mathrm{meq} / \mathrm{L}) \\
\text { Intact serum } \mathrm{PTH}(\mathrm{pg} / \mathrm{mL})\end{array}$ & 30.2 & 34.7 & $7-53$ \\
\hline
\end{tabular}

PTH-parathormone

Development of hypocalcaemia in response to hypermagnesaemia has been well documented [2]. Low serum calcium has been observed in patients with tetanus on magnesium sulphate therapy in Sri Lanka [3]. Absence of clinical signs of hypocalcaemia in this patient despite the low serum calcium is similar to the findings in earlier studies $[1,3]$. Most of the patients on intravenous magnesium sulphate therapy are under sedation and therefore unable to complain of early symptoms of hypocalcaemia such as paraesthesia, circumoral numbness and cramps. Hence, hypocalcaemia can persist unnoticed, leading to dangerous complications such as convulsions, laryngeal stridor, dystonia, psychosis and cardiac arrhythmias. Thus, close monitoring of serum calcium level is imperative in patients on intravenous magnesium sulphate.

\section{References}

1. Cholst IN, Steinberg SF, Tropper PJ, Fox HE, Segre GV, et al. The influence of hypermagnesaemia on serum calcium and parathyroid hormone levels in human subjects. New England Journal of Medicine 1984; 310: 1221-5.

2. Monif GRG, Savory J. Iatrogenic maternal hypocalcaemia following magnesium sulfate therapy. Journal of the American Medical Association 1972; 219: 1469-70.

3. Attygalle D, Rodrigo N. Magnesium sulphate for control of spasms in severe tetanus. Can we avoid sedation and artificial ventilation? Anaesthesia 1997; 52: 956-62.

1'Intern Medical Officer, Professorial Medical Unit, Teaching Hospital, Colombo South; 2, 3Senior Lecturers, Department of medicine, Faculty of Medical Sciences, University of Sri Jayawardenepura, Sri Lanka.

Correspondence:ESW, e-mail:<erangasw@yahoo.com> and <eranga@sjp.ac.lk> (Competing interests:none declared). Received 25 April 2004 and revised version accepted 14 June 2004. 